\title{
https://dx.doi.org/10.4314/iijikm.v10i2.9 \\ Job Satisfaction among Library Personnel in Public Universities in South-West Nigeria
}

\author{
Rosaline Opeke ${ }^{1}$ \\ Chinyere Nkechi Ikonne ${ }^{2}$ \\ Omobola Olufunke Adewoyin ${ }^{3}$ \\ Department of Information Resources Management \\ Babcock University, Nigeria ${ }^{\mathbf{1 2 3}}$ \\ Corresponding Author: adewoyinomobola@yahoo.com
}

\begin{abstract}
Job satisfaction is an indispensable factor for the success of every organization. It is a general concern to both employers and employees in organizations including universities libraries in Nigeria. Lack of job satisfaction could lead to poor service delivery in university libraries. Therefore, this study investigated job satisfaction among library personnel in public universities in South-West, Nigeria. The study was based on Herzberg two-factor theory. The dimensions of job satisfaction that the study covered included salary, job security, supervision, relationship with co-workers, promotion and work itself. Survey research design was adopted for the study. Data was collected through a structured questionnaire from the professional and paraprofessional staff in university libraries in South-West, Nigeria. As a result of the manageable size of the library personnel, total enumeration was used. Thus, the population was made up of 346 professionals and paraprofessionals staff from the federal and state universities. A response rate of 76.6 was obtained. The collected data was analyzed using descriptive statistics such as mean and standard deviation. Findings revealed that the level of job satisfaction of the respondents was high. Contributing to this was satisfaction with job security, relationship with co-workers, work itself and recognition. The results also revealed although the level of job satisfaction of the respondents was high, they were not satisfied with their salary. Out of all the dimensions of job satisfaction, satisfaction with salary had the lowest mean. Thus, the study recommends that the problem of low salary should be tackled in order to improve the level of satisfaction with salary among library personnel.
\end{abstract}

Keywords: Job Satisfaction, Library Personnel, Public Universities, South-West, Nigeria

\section{Introduction}

Job satisfaction of workers has been a major issue in the field of human resources, psychology and organizations (Mabaso, 2017). Job satisfaction has been defined by Ezeamama (2019) as the level to which workers like their work. It is the attitude displayed by workers towards their jobs. Job satisfaction involves doing a job one loves, doing it well and being compensated.
It also implies eagerness and pleasure with the job. It is an essential component of psychological wellbeing of workers. The influence of job satisfaction on happiness and well-being is undeniable (Ayele, 2014). Job satisfaction has been an issue of concern in every organization irrespective of the organizational structure. Satisfied workers are recognized for good performance. Job satisfaction of employees plays a crucial role 
in determining the general productivity of workers in every organization.

Job satisfaction is the attitude of the employees towards their wages, working conditions, promotion, and recognition. It is an essential factor for personal fulfillment in the course of carrying out one's duty. Ansong (2018) opine that it is essential for organizations to satisfy their workers in order to motivate them to work hard. According to him, job satisfaction is the expression of happiness that workers show towards their work, as a result of certain benefits they get from their job, which affect their decision to stay in the organization for a long period. Job satisfaction is the attitude displayed by workers towards their jobs. It has to do with the perceptions of workers towards their salaries, co-workers, supervision, policies of the organizations, and the promotion opportunities. It is usually perceived to be directly connected to productivity and personal well-being.

Job satisfaction has to do with the perceptions of workers towards their salaries, co-workers, supervision, policies of the organizations, and the promotion opportunities. It is usually perceived to be directly connected to productivity and personal well-being. Job satisfaction of library personnel is necessary for the achievement of the goals of university. This study, therefore, investigated job satisfaction among library personnel in public universities in South-West, Nigeria.

\section{Statement of the Problem}

Job satisfaction is an indispensable factor for the success of every organization. It is a general concern to both employers and employees in organizations including universities libraries in Nigeria. Job satisfaction is essential for workers to remain committed and improve their performance in their organizations. Lack of job satisfaction could result lead low productivity and inefficiency. Studies have shown that the level of job satisfaction of library personnel was low (Idiegbeyan-Ose, 2017, Oyovwevotu, 2017). It is a threat to information service delivery in the university libraries. Consequently, this study examined job satisfaction of library personnel in public universities in SouthWest, Nigeria.

\section{Objective of the Study}

The study investigated the level of job satisfaction of library personnel in public universities in South-West, Nigeria. The specific objectives of this study were to: 
1. find out the level of satisfaction of library personnel in public universities in South-West, Nigeria with their salary;

2. find out the level of satisfaction of library personnel in public universities in South-West, Nigeria with their supervisors;

3. find out the level of satisfaction of library personnel in public universities in South-West, Nigeria with relationship with their coworkers;

4. find out the level of satisfaction of library personnel in public universities in South-West, Nigeria with the promotion opportunities.

\section{Review of Literature}

Job satisfaction is one of the key factors for the success of any organization. Baro, Fyneman and Zoukemefa (2013) investigated the level of job satisfaction among cataloger librarians in university libraries in Nigeria. The results revealed that catalogers in university libraries in Nigeria were dissatisfied with roles, responsibilities, workplace culture, rewards (salaries/benefits), and professional development while they were satisfied with administration, supervision, performance evaluation, and opportunities. Ola and Adeyemi (2012) investigated motivation and job satisfaction of library personnel. The findings revealed that the morale of staff in the target group was doused due to frustration resulting from lack of involvement in decision making and inadequate among others. The study by Oyovwevotu (2017) revealed that librarians' level of job satisfaction in public universities in Nigeria was low.

Yaya (2017) found that job satisfaction of library personnel was high. Badia and Madawaki (2016) found that the level of job satisfaction of the library personnel was low. Majority of the respondents were not satisfied with their jobs. Oluchi (2012) studied job satisfaction among librarians in academic libraries in Nigeria. The results revealed that the level of job satisfaction among the respondents was commendable. Thornton (2000) identified some of the sources of dissatisfaction and points out areas of satisfaction of librarians. Adio and Popoola (2010) found that job satisfaction has significant influence on career commitment of librarians working in the federal university libraries. 
Amune (2013) surveyed job motivation as a predictor of job satisfaction among library personnel. The results showed that there were motivational packages that significantly predicted the satisfaction of library staff and there was no significant difference between the satisfaction derived by professional and nonprofessional library staff. The study further showed that library staff derived most satisfaction from salary, library policies, administration, advancement personal growth and job security. Ikonne and Haliso (2014) explored the influence of spatial comfort and environmental workplace ergonomics on the job satisfaction of librarians in the Federal and State university libraries in Southern Nigeria. The study adopted the survey research design. The results showed that there was a positive relationship between ergonomics and job satisfaction.

Hart (2010) investigated job satisfaction among library personnel in a university in South Africa. Hart stated that dissatisfaction was most strongly associated with stagnation, frustration poor remuneration etc. Ikonne and Onuoha (2015) conducted a study which investigated factors influencing the job satisfaction of library personnel in university libraries in Nigeria. The results revealed that job security, satisfactory relationship with supervisor, satisfactory interaction with colleagues and satisfactory interaction with information user/customer/ clients were significant factors that influenced the librarians' job satisfaction.

Bello (2007) investigated cataloguing practices and job satisfaction in Nigerian academic libraries. The study revealed that the respondents were highly satisfied. Baro, Seimode, and Godfrey (2014) that cataloguers in federal university libraries were more satisfied with their job than their private university colleagues. Leysen and Boyston (2009) investigated job satisfaction of cataloger librarians. The results showed that respondents were satisfied with their jobs. Job facets that cataloger librarians found most important were the benefits package, relationships with coworkers, and opportunities to learn new skills. A lot of them agreed that their supervisors were competent managers. Majority felt that their supervisors had confidence in their abilities and judgment.

Igbokwe (2010) investigated job satisfaction and performance of librarians in 
federal university libraries in South East Nigeria. The results revealed that job satisfaction existed among the respondents in federal university libraries in South East, Nigeria. The job satisfaction was associated to factors such as opportunity for promotion, good working environment and salary. It also revealed that job satisfaction had great influence on job performance. Igbasha, Beetseh, and Kumba (2016) investigated factors affecting job satisfaction of library personnel in Nigeria. The study revealed that job security, satisfactory relationship with my supervisor, satisfactory interaction with colleagues and satisfactory interaction with users were important factors that influenced the librarians' job satisfaction. Satisfaction with salary and fringe benefits, working condition, and opportunities to conduct research were rated low.

Sa'adatu, Sanusi, Ekoja, and Aduku (2015) examined job satisfaction of teacher librarians in the Federal Capital Territory (FCT). The study revealed that the teacher librarians had high level of job satisfaction. Onuoha, Samuel and Ojo (2014) investigated the influence of gender on job satisfaction of library personnel. The results revealed that majority of the staff were moderately satisfied with their job. Chuks-
Ibe and Ozioko (2014) investigated the problems militating against job satisfaction among librarians in academic libraries in Nigeria. The results showed that lack of opportunities for socialization and promotion, lack of managerial skills by administrators and poor library equipment were some of the challenged associated with job satisfaction.

Yaya, opeke and Onuoha (2016) examined the link between job satisfaction and productivity of librarians in universities in Nigeria. The results revealed that the level of job satisfaction was high. Amune (2014) investigated determinants of job satisfaction among male and female librarians in a university library. The results showed that female librarians in public university libraries were more satisfied with their jobs than their male colleagues. The results of the research by Idiegbeyanose (2018) revealed that the level of job satisfaction of respondents was low. Poor recognition and working environment provided by their organizations were the reasons for their low level of job satisfaction. The results of the research by Adio and Popoola (2010) showed that librarians in federal university libraries were highly satisfied with their jobs. Adigwe and 
Oriola (2015) found that the degree and level of satisfaction derived from one's job was sine qua non to the level of productivity.

Saka, Akor and Opaleke (2016) studied the influence of job satisfaction on the performance of library personnel in university libraries. Herzberg's two factor theory was the theory in which the theory was based. The results revealed that there was no significant relationship between job satisfaction and job performance among the library personnel. The study recommended that intrinsic and extrinsic factors should be applied. Ranaweera and $\mathrm{Li}$ (2018) found that the library personnel were moderately satisfied with their jobs. They were mostly satisfied with nature of work and coworkers. They were least satisfied with career development opportunities, salary and benefits. The study recommended increase in salary of the personnel. Moreover, the study recommended that management should support staff in their career development.

Igbokwe (2010) investigated job satisfaction and performance of librarians in federal university libraries in South East Nigeria. The results revealed that job satisfaction existed among the respondents in federal university libraries in South East Nigeria. The job satisfaction was associated to factors such as opportunity for promotion, good working environment and salary. Omolase (2008) points that a range of factors that influence an employee's level of job satisfaction include salary, perceived fairness of promotion system, good working condition, social relationships, leadership and the work itself.

The results of the study conducted by Akpa, Soetan, Nwankwere, and Magaji (2016) revealed that job satisfaction with coworkers was the highest rated job satisfaction variable, followed by satisfaction with work itself, advancement opportunities, supervision, promptness of salary payment, working conditions, promotion opportunities, and recognition. The satisfaction with benefits and pay had the least average positive response. Akintayo (2018) found that university registry personnel were satisfied with their jobs. They indicated that they were very satisfied with the nature of work and were satisfied with responsibility, achievement, and recognition while satisfaction with promotion recorded a low level. It was recommended that the university 
administrator should look into the factors that that are important to enhance job satisfaction of the university registry personnel.

Badawi (2006) explored the levels of job satisfaction of female librarians in Nigeria. The results of the study revealed that female librarians in Nigeria are very satisfied with achievement, interpersonal relationships, recognition, growth/advancement, work itself, salary, personal life and job security. They reported moderate satisfaction with supervision and responsibility.

\section{Theoretical Framework}

Although there are many theories on job satisfaction, Herzberg's two factor theory was used for the study because it is relevant to the study.

\section{Herzberg's Two Factor Theory}

Herzberg's two factor theory is also known as the motivation hygiene theory. The theory was developed by a psychologist, Frederick Herzberg in 1959. Herzberg stated that the factors that lead to satisfaction were different from those leading to dissatisfaction (Perumalsami, 2014; Igbeneghu \& Popoola, 2011; Wairrach 2013). He conducted research to determine which factors in an employee's work environment caused satisfaction or dissatisfaction. He found that people who felt good about their jobs gave very different responses from the people who felt bad about their jobs (Ogunnaike, Ekweme, Adeyemo \& Okedurum, 2017). His findings indicate that poor working conditions lead to dissatisfaction, however, this does not mean that good working conditions would result in job satisfaction either (Booysen, 2008).

\section{Methodology}

The study adopted survey research design. Survey research design is proper for collecting primary data from a large population because it reflects the opinions and attitudes of respondents about the subject matter (Akomolafe, 2019). This study sought to obtain data on job satisfaction of library personnel in public universities in South-West, Nigeria. The design was appropriate for the study because opinions of library personnel were the source of data collection.

The population of the study comprised of professionals and paraprofessional staff in the public universities in South-West, Nigeria. It comprised of 347 of the personnel in the public universities in South-West, Nigeria. 
The sample comprised of the professional and paraprofessional staff in the federal and state universities in South-West Nigeria. As a result of the manageable size of the library personnel, total enumerative was used. Hence, the entire population of the library personnel in both federal and state universities was the sample size. The six states in the South-West geopolitical zone of Nigeria are Ekiti, Lagos, Ogun, Ondo, Osun and Oyo. The research instrument that was used for data collection was questionnaire. The instrument measured job satisfaction of the library personnel. The instrument was developed by the researcher. The questionnaire was distributed and collected by the researcher and research assistants.

\section{Results}

The study sought to know the level of job satisfaction of library personnel in public universities in South-west, Nigeria. The Table presents the results.

\section{Level of job satisfaction of library personnel in public universities in South-West, Nigeria}

\begin{tabular}{|c|c|c|c|c|c|c|c|c|}
\hline $\begin{array}{l}\mathbf{S} / \\
\mathbf{N}\end{array}$ & Salary & $\begin{array}{l}\text { Highl } \\
\text { y } \\
\text { satisfi } \\
\text { ed }\end{array}$ & $\begin{array}{l}\text { Satisfi } \\
\text { ed }\end{array}$ & $\begin{array}{l}\text { Modera } \\
\text { tely } \\
\text { satisfie } \\
\text { d }\end{array}$ & $\begin{array}{l}\text { Dissat } \\
\text { isfied }\end{array}$ & $\begin{array}{l}\text { Highl } \\
y \\
\text { dissat } \\
\text { isfied }\end{array}$ & Mean & SD \\
\hline $\mathbf{1}$ & $\begin{array}{l}\text { Sufficiency of salary to meet } \\
\text { personal and family expenses }\end{array}$ & $\begin{array}{c}24 \\
(9.1)\end{array}$ & $\begin{array}{c}79 \\
(29.9)\end{array}$ & $\begin{array}{c}100 \\
(37.9)\end{array}$ & $\begin{array}{c}32 \\
(12.1)\end{array}$ & $\begin{array}{c}29 \\
(11.0)\end{array}$ & 3.14 & 1.10 \\
\hline \multirow[t]{2}{*}{2} & $\begin{array}{l}\text { Fairness of salary with the amount } \\
\text { of work }\end{array}$ & $\begin{array}{c}22 \\
(8.4)\end{array}$ & $\begin{array}{c}91 \\
(34.6)\end{array}$ & $\begin{array}{c}96 \\
(36.5)\end{array}$ & $\begin{array}{c}34 \\
(12.9)\end{array}$ & $\begin{array}{c}20 \\
(7.6)\end{array}$ & 3.23 & 1.03 \\
\hline & Job Security & & & & & & & \\
\hline 3 & Level of job security & $\begin{array}{c}77 \\
(29.3)\end{array}$ & $\begin{array}{c}119 \\
(45.2)\end{array}$ & $\begin{array}{c}43 \\
(16.3)\end{array}$ & $\begin{array}{c}15 \\
(5.7)\end{array}$ & $\begin{array}{c}9 \\
(3.4)\end{array}$ & 3.91 & 0.94 \\
\hline \multirow[t]{2}{*}{4} & Permanence & $\begin{array}{c}86 \\
(33.0)\end{array}$ & $\begin{array}{c}103 \\
(39.5)\end{array}$ & $\begin{array}{c}50 \\
(19.2)\end{array}$ & $\begin{array}{c}15 \\
(5.7)\end{array}$ & $\begin{array}{c}7 \\
(2.7)\end{array}$ & 3.94 & 0.99 \\
\hline & Supervision & & & & & & & \\
\hline 5 & $\begin{array}{l}\text { Handling of personal and work- } \\
\text { related issues by supervisors }\end{array}$ & $\begin{array}{c}39 \\
(14.9) \\
\end{array}$ & $\begin{array}{c}123 \\
(46.9) \\
\end{array}$ & $\begin{array}{c}65(24.8 \\
)\end{array}$ & $\begin{array}{c}26 \\
(24.8) \\
\end{array}$ & $\begin{array}{c}10 \\
(3.8)\end{array}$ & 3.60 & 0.98 \\
\hline \multirow[t]{2}{*}{6} & $\begin{array}{l}\text { Trust in my supervisors for their } \\
\text { encouragement }\end{array}$ & $\begin{array}{c}47 \\
(17.9)\end{array}$ & $\begin{array}{c}109 \\
(41.6)\end{array}$ & $\begin{array}{c}72 \\
(27.5)\end{array}$ & $\begin{array}{c}25 \\
(9.5)\end{array}$ & $\begin{array}{c}9 \\
(3.4)\end{array}$ & 3.61 & 0.99 \\
\hline & Relationship with co-workers & & & & & & & \\
\hline 7 & $\begin{array}{l}\text { Competency of co-workers in their } \\
\text { job }\end{array}$ & $\begin{array}{c}53 \\
(20.3) \\
\end{array}$ & $\begin{array}{c}125 \\
(47.9) \\
\end{array}$ & $\begin{array}{c}63 \\
(24.1) \\
\end{array}$ & $\begin{array}{c}15 \\
(5.7) \\
\end{array}$ & $\begin{array}{c}5 \\
(1.9) \\
\end{array}$ & 3.79 & 0.90 \\
\hline \multirow[t]{2}{*}{8} & Co-operative among co-workers & $\begin{array}{c}65 \\
(24.9) \\
\end{array}$ & $\begin{array}{c}111 \\
(42.5)\end{array}$ & $\begin{array}{c}68 \\
(26.1) \\
\end{array}$ & $\begin{array}{c}11 \\
(4.2)\end{array}$ & $\begin{array}{c}6 \\
(2.3) \\
\end{array}$ & 3.84 & 0.93 \\
\hline & Recognition & & & & & & & \\
\hline
\end{tabular}




\begin{tabular}{|c|c|c|c|c|c|c|c|c|}
\hline 9 & $\begin{array}{l}\text { Recognition and respect given for } \\
\text { personal efforts }\end{array}$ & $\begin{array}{c}42 \\
(15.9)\end{array}$ & $\begin{array}{c}117 \\
(44.3)\end{array}$ & $\begin{array}{c}84 \\
(31.8) \\
\end{array}$ & $\begin{array}{c}13 \\
(4.9)\end{array}$ & $\begin{array}{c}8 \\
(3.0) \\
\end{array}$ & 3.65 & 0.91 \\
\hline \multirow[t]{2}{*}{10} & $\begin{array}{l}\text { Recognition given for group } \\
\text { achievement }\end{array}$ & $\begin{array}{c}44 \\
(16.9)\end{array}$ & $\begin{array}{c}106 \\
(40.6)\end{array}$ & $\begin{array}{c}89 \\
(34.1)\end{array}$ & $\begin{array}{c}9 \\
(3.4)\end{array}$ & $\begin{array}{c}13 \\
(4.9)\end{array}$ & 3.61 & 0.97 \\
\hline & $\begin{array}{c}\text { Promotion and advancement } \\
\text { opportunities }\end{array}$ & & & & & & & \\
\hline 11 & $\begin{array}{l}\text { Opportunities provided for } \\
\text { promotion }\end{array}$ & $\begin{array}{c}59 \\
(22.3)\end{array}$ & $\begin{array}{c}100 \\
(37.9)\end{array}$ & $\begin{array}{c}81 \\
(30.7)\end{array}$ & $\begin{array}{c}15 \\
(5.7)\end{array}$ & $\begin{array}{c}10 \\
(3.4)\end{array}$ & 3.70 & 0.99 \\
\hline \multirow[t]{2}{*}{12} & $\begin{array}{l}\text { Selection criteria followed for } \\
\text { promotion }\end{array}$ & $\begin{array}{c}45 \\
(17.1) \\
\end{array}$ & $\begin{array}{c}96 \\
(36.5) \\
\end{array}$ & $\begin{array}{c}86 \\
(32.7) \\
\end{array}$ & $\begin{array}{c}27 \\
(10.3) \\
\end{array}$ & $\begin{array}{c}9 \\
(3.4) \\
\end{array}$ & 3.54 & 1.00 \\
\hline & Growth/Career development & & & & & & & \\
\hline 13 & $\begin{array}{l}\text { Interest shown by the management } \\
\text { in career development of staff }\end{array}$ & $\begin{array}{c}35 \\
(13.3)\end{array}$ & $\begin{array}{c}114 \\
(43.2)\end{array}$ & $\begin{array}{c}73 \\
(27.7)\end{array}$ & $\begin{array}{c}27 \\
(10.2)\end{array}$ & $\begin{array}{c}15 \\
(5.7)\end{array}$ & 3.48 & 1.03 \\
\hline \multirow[t]{2}{*}{14} & $\begin{array}{l}\text { Opportunities provided for career } \\
\text { development of staff }\end{array}$ & $\begin{array}{c}38 \\
(14.5) \\
\end{array}$ & $\begin{array}{c}114 \\
(43.5) \\
\end{array}$ & $\begin{array}{c}80(30.5 \\
)\end{array}$ & $\begin{array}{c}18 \\
(6.9) \\
\end{array}$ & $\begin{array}{c}13 \\
(4.6) \\
\end{array}$ & 3.56 & 0.98 \\
\hline & Work itself & & & & & & & \\
\hline 15 & $\begin{array}{l}\text { Feeling of fulfillment in the work I } \\
\text { am engaged in }\end{array}$ & $\begin{array}{c}46 \\
(17.4)\end{array}$ & $\begin{array}{c}132 \\
(50.0)\end{array}$ & $\begin{array}{c}64 \\
(24.2)\end{array}$ & $\begin{array}{c}18 \\
(6.8)\end{array}$ & $\begin{array}{c}4 \\
(1.5)\end{array}$ & 3.75 & 0.88 \\
\hline 16 & Clarity of job description & $\begin{array}{c}57 \\
(21.8)\end{array}$ & $\begin{array}{c}107 \\
(40.8)\end{array}$ & $\begin{array}{c}85 \\
(32.4)\end{array}$ & $\begin{array}{c}10 \\
(3.8)\end{array}$ & $\begin{array}{c}3 \\
(1.1)\end{array}$ & 3.78 & 0.87 \\
\hline
\end{tabular}

Field survey, 2019

The Table shows that the level of job satisfaction of library personnel in public universities in South-West, Nigeria was high. The Table gives details of the level of job satisfaction of library personnel in public universities examined in this study. The table shows all the indicators used in the study (salary, job security, supervision, relationship with co-workers, recognition, promotion and advancement opportunities, and work itself. The table reveals the average mean score to the responses to each indicator of job satisfaction and the overall mean score for all the indicators. The table also shows that the level of job satisfaction of library personnel in public universities was high, with the mean score of 3.63 on a five -point scale. This shows that library personnel in public universities were highly satisfied with their job. Contributing to this was job security which had the highest mean of 3.93, with level of job security and permanence of job had mean of 3.91 and 3.94 respectively.

This was followed by relationship with co-workers (i.e. competency of coworkers in their job and cooperative among co-workers had mean of $\mathrm{M}=3.79$ and $\mathrm{M}$ $=3.84)$. Work itself $(M=3.77)$ (i.e. feeling of fulfillment in the work that library 
respondents are engaged in and clarity of job description had $\mathrm{M}=$ of 3.75 and $\mathrm{M}=3.78$. Salary had the lowest mean M=3.19(i.e. sufficiency of salary to meet personal and family expenses had $\mathrm{M}=3.14$ fairness of salary with the amount of work of the library personnel had $\mathrm{M}=3.23$. This implies that the respondents were not satisfied with their salary. When workers feel that their salary cannot meet their needs, their commitment to their organizations might decrease.

\section{Discussion of Findings}

The study examined level of job satisfaction of library personnel in public universities in South-West, Nigeria. This section reports the findings of this study and discusses the findings in line with previous studies. The results revealed a high level of job satisfaction among library personnel in public universities in South-West, Nigeria. The finding is in agreement with earlier studies carried out by Ezeamama (2019), Ekere and Ugwu (2011), Yaya (2017), and Kolo (2018). Ekere and Ugwu (2011) investigated the influence of personal characteristics of librarians on their job satisfactions in University Libraries in Nigeria and found a high level job satisfaction among the library personnel. Yaya (2017) also found that the level of job satisfaction of librarians in university libraries was high. Kolo (2018) also reported that the workers had high level of job satisfaction.

Similarly, the finding agreed with Adigwe and Oriola (2014) and Onuoha, ogunjimi and Owodunni (2016). Adigwe and Oriola (2014) reported that the majority of the respondents expressed satisfaction with their jobs indicating that the level of job satisfaction among special library personnel in Southwest Nigeria was very high. Onuoha, Ogunjimi and Owodunni (2016) investigated the relationship between self-concept, role clarity and the job satisfaction of library personnel in selected university libraries. The results revealed a high level of self-concept, role clarity and job satisfaction among respondents. The implication of this is that the personnel have positive attitude towards their jobs attitude which will definitely result to increase their commitment and productivity.

However, the result disagreed with similar studies conducted by Oyovwevotu (2017), Idiegbeyan-Ose (2018), IdiegbeyanOse, Opeke, Aregbesola, Owolabi and EyiOlorunshe (2019). Idiegbeyan-Ose, Opeke, Aregbesola, Owolabi and 
EyiOlorunshe (2019) investigated the relationship between motivation and job satisfaction of library personnel in university libraries in Nigeria. The results show that the library staff job satisfaction was low. Oyovwevotu (2017) reported that the level of job satisfaction of librarians in public universities in Nigeria was low.

Another major finding of this study was that the library personnel were not satisfied with their salary. Out of all the dimensions of job satisfaction, satisfaction with pay had the lowest mean. Satisfaction with pay was rated low. This result corroborates with Ikonne and Onuoha (2015) Daship (2012), and Ikolo (2017) who reported that library personnel were not satisfied with their salary. Esakkimuthu and Vellaichamy (2015) noted that salary is a vital enticement that entices and retains the workers in organizations. According to them, timely dissemination of information to patrons can be enhanced only when library personnel have high commitment. It is important to know the level of job satisfaction of workers, since the level of job satisfaction achieved by workers would assist to develop policies not only to improve the level of satisfaction but also for the efficient practice of the privatization policy (Gopinath \& Kalpana, 2019). Consequently, this study concluded that the level of job satisfaction of library personnel in universities was high. As a result of this, it is assumed that productivity of the staff is high and there is low turnover.

\section{Conclusion and Recommendations}

The study examined job satisfaction of library personnel in public universities in South-west, Nigeria. Survey design was used for the study. The level of job satisfaction of library personnel in public universities in South- West, Nigeria was high. Factors such as job security, relationship with co-workers and work itself contributed to the high level of job satisfaction of these personnel.

The study revealed the level of job satisfaction of library personnel in public universities was high. The library management should sustain the level of job satisfaction of their personnel. The study revealed that although the level of job satisfaction of library personnel in public universities was high; the personnel were not satisfied with their salaries. Thus, the federal government should tackle the problem of low salary among their workers. 


\section{References}

Adigwe, I. \& Oriola, J. (2015). Towards an understanding of job satisfaction as it correlates with organizational change among personnel in computer-based special libraries in South-West Nigeria. The Electronic Library, 33 (4), 773-794.

Adio, G. \& Popoola, S. O. (2010). Job satisfaction and career commitment of librarians in federal university libraries in Nigeria. Library Review, 59 (3), 175-184.

Akintayo, O. (2018). Information culture, records management practices, work environment on job satisfaction among registry personnel in universities. (Doctoral dissertation). Babcock University, Ogun State, Nigeria.

Akomolafe, M. (2019). Health information literacy, mobile phone use and quality of life of pregnant women in Ekiti State, Nigeria. (Doctoral dissertation). Babcock University, Ogun State, Nigeria.

Akpa, V., Soetan, T., Nwankwere, I., \& Magaji, N. (2016). An investigation of influence of job satisfaction on employees' intention to leave: an empirical study of selected private universities in South West Nigeria. International Journal of Advanced Engineering and Management Research, 1(5), 592-613.

Amune, J. B. (2013). Job Motivation as a predictor of job satisfaction among professional and nonprofessional library staff in Ambrose Alli University, Ekpoma. International Journal of Innovative Research \& Development, 2 (5), 1477-1497.

Amune, J. B. (2014). A comparative study of the determinants of job satisfaction among male and female librarians in public university libraries in Edo State of Nigeria. International Journal of Education and Research, 2 (7), 649-660.

Ansong, J. (2018). Job satisfaction among career records personnel in the civil service of Ghana. University of Ghana, Ghana. (MPhil Thesis).

Ayele, D. (2014). Teachers' job satisfaction and commitment in general secondary schools of Hadiya zone, in Southern nation nationality and people of regional state (Master's thesis). Jimma University.

Badawi, G. (2006). Factors affecting the levels of job satisfaction of female librarians in Nigeria: A test of Herzberg's hygiene/motivator factors. Samaru Journal of Information Studies, 6 (1\&2), 6-12.

Badia, M., \& Madawaki, Z. (2016) Salary/fringe benefit as correlation of job commitment of librarians in federal university libraries in the North -Eastern, Nigeria. Nigerian Libraries, 49(1 \&2), 89-97.

Baro, E., Fyneman, B., \& Zoukemefa, T. (2013). Job satisfaction among cataloger librarians in 
university libraries in Nigeria. Cataloging \& Classification Quarterly, 51(6), 675-696.

Baro, E., Seimode, F., \& Godfrey, V. (2014). A comparative study of job satisfaction between cataloguers in federal and private university libraries in Nigeria. African Journal of Library, Archives and Information Science, 24(2), 161-173.

Bello, M. A. (2007). A survey of cataloguing practices and job satisfaction in Nigerian academic libraries. Ghana Library Journal, 19(2): 73-87.

Booysen, C. (2008). A study of the relationship between job satisfaction experienced by employees within a retail company and their organizational citizenship behavior. (Master's thesis), University of the Western Cape.

Chuks-Ibe, P. \& Ozioko, R. (2014). Problems militating against job satisfaction among librarians in academic libraries in Niger state, Nigeria. The Information Technologist, 11(1).

Daship, N. (2012). Job satisfaction and job performance of library personnel of national library of Nigeria. (Master's thesis). University of Nigeria, Nigeria.

Ekere, J., \& Ugwu, I. (2011). Influence of age, gender and working experience on librarians’ job satisfaction in University libraries in Nigeria. Information Impact: Journal of Information and Knowledge Management, 2(1), 1-14.

Esakkimuthu, C., \& Vellaichamy, A. (2015). Job satisfaction among the library professionals in engineering institutions: An empirical study. International Journal of Digital Library Services, 5 (1), $22-37$.

Ezeamama, I. G. (2019). Job satisfaction and employee productivity in Anambra state Nigeria European Journal of Research in Social Sciences. 7 (2), 1-13.

Gopinath, R., \& Kalpana, R. (2019). Employees' job satisfaction working at hospitals in Perambalur district. Journal of emerging technologies and innovative research, 6(4), 220225.

Hart G. (2010). Job satisfaction in a South African academic library in transition. Journal of Academic Librarianship 36(1): 53-62.

Idiegbeyanose, J. (2017). Leadership style, organizational culture and staff motivation as correlates of job satisfaction and turnover intention in private university libraries in South-West, Nigeria. (Doctoral dissertation). Babcock University, Ogun State, Nigeria.

Idiegbeyanose, J. (2018). An investigation on the nexus between leadership style and job satisfaction of library staff in private university libraries South-West, Nigeria. Library Philosophy and Practice (e-journal).

Idiegbeyan-Ose, J., Opeke, R., Aregbesola, A., Owolabi, S., \& Eyiolorunshe, T. (2019). Relationship between motivation and job satisfaction of staff in private university libraries, 
Nigeria. Academy of strategic management, 18(1), 1-13.

Igbashal, A., Beetseh, K., \& Kumba, L. (2016). Factors affecting librarians job satisfaction in federal University of Agriculture, Makurdi. Library. Inter. J. Acad. Lib. Info. Sci. 4(9), 264270.

Igbeneghu, B., \& Popoola, S. (2011). Influence of locus of control and job satisfaction on organizational commitment: a study of medical records personnel in University teaching theory. Library Philosophy and Practice.

Igbokwe, P. (2011). Job satisfaction and performance of librarians in federal university libraries in South East Nigeria. (Master's thesis). University of Nigeria, Nsukka.

Ikolo, V. (2017). Influence of job Satisfaction on job performance: A study of teacher librarians in Delta State Nigeria. Journal of Information and Knowledge Management.8 (4), 43 - 50.

Ikonne, C. \& Onuoha, U. (2015). Factors influencing job satisfaction of librarian in federal and state university libraries in Southern Nigeria. Open Access Library Journal, 2(2), 1-9.

Ikonne, C. \& Haliso, Y. (2014). Influence of spatial comfort and environmental workplace ergonomics on job satisfaction of librarians in the Federal and State University Libraries in Southern Nigeria. Open Access Library Journal, 1, 1-10

Kolo, E.S. (2018). Job satisfaction among healthcare workers in a tertiary center in Kano, Northwestern Nigeria. Niger J Basic Clin Sci, (15), 87-91.

Leysen, J., \& Boyston, J. (2009). Job satisfaction among academic cataloger librarians. College

Research Libraries, 273-297.

Mabaso, C., \& Dlamini, B. (2017). Impact of compensation and benefits on job satisfaction. Research Journal of Business Management. 11 (2), 80-90.

Ogunnaike, O., Ekweme, B., Adeyemo, O., \& Okedurum, D. (2017) The Frederick Herzberg two factor theory of job satisfaction and its application to business research. In: CUCEN 2017, Covenant University, Ota.

Ola, C. O. \& Adeyemi, B. (2012). Motivation, job satisfaction and service delivery: mid-level staff at Kenneth Dike library, university of Ibadan, Nigeria. Library Philosophy and Practice (e-journal).

Oluchi, N. (2012). Job satisfaction among librarians in academic libraries in Niger state, Nigeria. (Master's thesis). University of Nigeria, Nsukka.

Omolase, C.O. (2008). Job satisfaction amongst medical practioners in a Nigerian community. Nigerian Hospital Practice, 2(1), 80-84. 
Onuoha, U., Samuel, T., \& Ojo, A. (2014). Gender and job satisfaction: A study of library staff in private university libraries in Ogun state, Nigeria. Journal of New Media and Mass and Mass Communication, 1(1), 12-19.

Onuoha, U., Ogunjinmi, T., \& Owodunni, M. (2016). Role clarity, self-concept and job satisfaction of library personnel in selected university libraries in Ogun State, Nigeria. Journal of applied and Journal of Applied Information Science and Technology, 9 (2), 9-16.

Oyovwevotu, L. (2017). Institutional support, job satisfaction and employees' commitment in public university libraries in South-East geo-political zone, Nigeria. (Doctoral dissertation). Babcock University, Ogun State, Nigeria.

Perumalsami, J. (2014). The relationship between job satisfaction and organizational citizenship behaviour in a Western Cape government office. (Master's thesis) Cape peninsula university of technology, Cape Town.

Ranaweera, R. \& Li, S. (2018). Exploring the job satisfaction of staff working in university libraries in Sri Lanka. Information and Knowledge Management.8 (3), 37-42.

Sa'adatu, L., Sanusi, I., Ekoja, I. \& Aduku, B. S. (2015). Assessment of teacher librarian job satisfaction in the Federal Capital Territory FCT Abuja. Samaru Journal of Information Studies 15(1-2),

Saka, K., Akor, P., \& Opaleke, J. (2016). Influence of motivation and job satisfaction on the job performance of staff in University Libraries in North Central Geo-political zone of Nigeria,

Nigerian Libraries, 49, (1\&2), 1-7.

Samuel, T., Onuoha, U., \& Ojo, A. (2014). Job Satisfaction and organizational commitment: A Study of Library Personnel in Private Universities in Ogun State, Nigeria. Open Access Library Journal, 1, 1-8.

Thornton, J. (2000). Job Satisfaction of librarians of African descent employed in ARL academic libraries. College \& Research Libraries 6, 217-232.

Wairrach, N. (2013). Motivational preferences of LIS Professionals in university libraries of Pakistan. Library Philosophy and Practice(e-journal).

Yaya, J., Opeke, R., \& Onuoha, U. (2016). Job satisfaction as correlates of librarians' productivity in public university libraries in Nigeria. Library Philosophy and Practice (E-Journal).

Yaya, J. (2017). Correlational analysis of motivation, emotional intelligence and human capital development on librarians' job satisfaction and productivity in public university libraries in

Nigeria. Library Philosophy and Practice (e-journal). 